\title{
Dual purpose cattle production in Mexico
}

\section{R. Rojo-Rubio • J. F. Vázquez-Armijo • \\ P. Pérez-Hernández • G. D. Mendoza-Martínez •}

A. Z. M. Salem • B. Albarrán-Portillo •

A. González-Reyna • J. Hernández-Martínez •

S. Rebollar-Rebollar • D. Cardoso-Jiménez •

E. J. Dorantes-Coronado • J. G. Gutierrez-Cedillo

Accepted: 15 October 2008 / Published online: 30 October 2008

(C) Springer Science + Business Media B.V. 2008 supplies and forages resources, as well as agricultural and agro-industrial by-products. Mexico is placed among the ten first meat and milk producer countries worldwide, being the Mexican tropical zone one of the main suppliers of such products. One of the main milk sources is the dual purpose cattle, such systems can be described as those that produce milk (daily milking) and meat (calf after weaning), on every productive cycle. They are mainly located in developing regions and characterized by using low-technology and in poor environments, consequently productive levels are considered low. Milk is destined for self-consumption or for sale at local markets and calf after weaning is sold at local feedlots or for export. Regarding to the little information available about the dual purpose systems, the present work is intended to discuss the main characteristics of cattle production in dual purpose systems in Mexico.

Keywords Dual purpose cattle $\cdot$ Milk production . Calf production $\cdot$ Mexico

$\begin{array}{ll}\text { Abbreviations } \\ \text { DPS } & \text { Dual Purpose Systems } \\ \text { PS } & \text { Production Systems } \\ \text { NAFTA } & \text { North American Free Trade Agreement } \\ \text { AGAR } & \text { Annual Growth Average Rate } \\ \text { Kg } & \text { Kilogram } \\ \text { L } & \text { Liter } \\ \text { t } & \text { Ton }\end{array}$


d Day

ha Hectare

\section{Introduction}

Cattle production in Mexico represents one of the main activities of the agricultural sector in the country, due to the variety of climatic regions, and due to that, the country offers great amounts of beef and dairy products. Therefore it holds the seventh place in worldwide bovine meat production, with $4.1 \%$, and tenth in worldwide dairy production, with 2.4\% (SAGARPA 2005; SAGARPA 2006).

Cattle production is carried out under different situations and production systems (PS), that vary from the traditional, low input, backyard type systems, principally operated by and oriented towards farming families and used as self-supply and income, to the hiinput, hi-technology as well as highly integrated and specialized dairy systems (Rivas and Holmann 2002). Management-wise, dual purpose systems (DPS) are classified as traditional or extensive and intensive or the combination of both, which is called semi-intensive.

The Mexican livestock industry has gone along the time through many changes, including the introduction of different dairy breeds, which has allowed the presence of a diversity of genotypes in the DPS in the country. Nonetheless, meat and milk production in Mexico has not to be self-sufficient, so it depends on the importations to meet the human demands (Magaña et al. 2006).

Currently, this sector is in a stand-by or uncertainty status, mainly induced by the world market globalization, particularly by the North American Free Trade Agreement (NAFTA), which allows the free importation of agricultural products and grains; in addition, the low terminal efficiency and productivity of the PS, in meat and milk production, besides, the lack of government development and the long term programs have responsible of this situation (Del Valle and Álvarez 1997).

The DPS is a system mostly suitable and developed for tropical regions of the world and the country and primarily its uses Zebu (Bos indicus) breeds as maternal lines and Brown Swiss, Braunvieh, Holstein, Jersey, Montbeliard and Simmental (Bos taurus), as paternal breeds. The system traditionally, uses undefined crossing schemes in an attempt to obtain, the highest hybrid vigor from both types of breeds. In a few instances, creole or native Bos taurus cattle has been used. It has two fundamental objectives, the first one, is milk production, regularly obtained manually and with the presence of the calf, to facilitate the milk let-down, and the second objective is the production of meat, in terms of the weaning calf (Rivera et al. 1989; Espinoza-García et al. 2000). These farms present differences and peculiarities determined by climatic and geographic conditions, as well as social and cultural factors (Gómez et al. 2002; Magaña et al. 2006). The present review attempts to discuss the main characteristics of cattle DPS Mexico.

\section{Dual purpose cattle production in Mexico}

Dual purpose systems in tropical regions of Mexico are intended to produce meat and milk at low cost, but it also has an aggregated value, that is, a labor generating scheme, as well. In Tropical America, it is estimated that approximately $78 \%$ of the cattle population, are managed under this system and it contributes $40 \%$ of the milk production (Rivas and Holmann 2002). In Mexico, cattle of the tropical regions provides $20 \%$ and $44 \%$ of the milk and meat consumed, respectively (SAGARPA 2005; SAGARPA 2006).

In Mexico, there are about 32 million head of cattle (SAGARPA 2006), 29\% corresponds to cattle in DPS. This system of production is located in the tropical region, which covers $28 \%$ of the national territory (INEGI 2008). The land used in these areas of production is distributed in grazing lands $(50 \%)$, induced pastures $(25 \%)$ and agricultural crops (25\%). In these regions, $80 \%$ of the DPS farms are located, and distributed, in several states, as follows, Veracruz (38\%), Las Huastecas (Tropical regions in the states of Tamaulipas, San Luis Potosí, Hidalgo and Veracruz, (19\%), Chiapas (16\%) and Tabasco (8\%) (Espinoza-García et al. 2000; Gómez et al. 2002; SAGARPA 2005).

The DPS is characterized by using the crosses from Bos taurus x Bos indicus breeds, and use of forages as main feed and single source for maintenance and milk production. In this system, calf remains with the cow, during a variable period and milking (GallegosSánchez 1990; Juárez et al. 1999).

Calf average weight gain was relatively low, reaching daily gains of $488\left( \pm 145 \mathrm{~g} \mathrm{~d}^{-1}\right)$ at 4 months of age, 360 
$\left( \pm 97 \mathrm{~g} \mathrm{~d}^{-1}\right)$ at 7 months of age and $395\left( \pm 81 \mathrm{~g} \mathrm{~d}^{-1}\right)$ at 10 months (Rodríguez-Chessani and Sordo 1995). The average weight at weaning was $150-156 \mathrm{Kg}$ (González-Padilla 1993; McDowell 1996). Calf mortality from the birth to weaning oscillates between 10 to $15 \%$. In addition, $63 \%$ of the losses were occurred within the two first months (e.g. 45 and $18 \%$ during the first and second months, respectively), after birth. The principal reasons of death in the first seven months of age include nutritional deficiencies and infections, diseases, e.g. ecto and endo parasites; and respiratory and gastrointestinal diseases.

With regards to reproductive parameters, the main problems are, delayed puberty, long intervals between parturitions and low conception percentages. The interval between parturitions births exceeds 500 days, mainly caused by the extensive postpartum anoestrus period, originated by the negative effects exerted by suckling and the feeding of cows with grass, with no supplements (nutritional deficiencies), which inhibits the reestablishment of ovarian activity postpartum (Pérez-Hernández 1992).

\section{Statistics on Mexican dual purpose cattle production}

Dual purpose cattle system produce as 1,600 million litter of milk annually that represents $19.5 \%$ of the national milk production per year and $50 \%$ of the meat production. Systems of production are very heterogeneous in management and productive parameters; nevertheless, the main differences are herd size, lactation days and milk yield (Table 1) (FIRA 2001).

In Mexico, the annual beef and milk production is reported as 1.5 million $\mathrm{t}$ and 10,000 million $\mathrm{L}$ respectively. Meat production had an annual growth average rate (AGAR) of $2.4 \%$ during the period of 1999-2000; and 1.8\% for 2000-2005, while milk production had an AGAR of 3.0\% during 1995-2005 (SAGARPA 2005; SAGARPA 2006).
In 2005 , the value of beef production was 4,108 million of Mexican pesos and the principal producers states were: Veracruz, Jalisco, Chiapas, Sonora and Chihuahua, contributing with 13.4, 11.4, 5.5, 5.1, and $4.9 \%$, respectively (SAGARPA 2006); whereas for 2003, the value of national milk production was as 3 million of Mexican pesos (Magaña et al. 2006).

\section{Use of nutritional techniques}

Pasture management and use of non-conventional forages

Traditionally, grazing lands and pastures have been managed as extensive grazing systems, with scarce or absent fertilization, giving rise to the problem of overgrazing, situation that compromises the system's sustainability. During the last ten years, concerns on the alarming grazing lands in vast regions in tropical zones has been on the rise; notwithstanding that, among the causes of these situations, the inappropriate regionalization of the grasslands, the inefficient management methods, lengthy droughts, over grassing, inefficient weed control among other causes, have been mentioned, it seems as thought the gradual loss of soil fertility, especially, the stressed diminution of easily assimilable nitrogen content is a weighty factor (Juárez et al. 1999; Ruiz et al. 2005).

Apparently, the establishment of vast extensions with single crops, or grasses, in livestock producing areas has been the fundamental cause of such deterioration process. The scarce plant biodiversity in livestock areas, linked to the inefficient mechanisms of nutrients recycling, has taken its toll, to large extent in the imbalance of these ecosystems (Ruiz et al. 2005). In order to solve this problem, farmers have used as a technologic option, the use of multipurpose plants in the animal production systems, as there is a large variety of species available. In general, it has been determined that this forage source contains more than

Table 1 Basic characteristics of dairy production systems in Mexico.

\begin{tabular}{llll}
\hline Characteristic & Specialized Semi-specialized & Family-owned & Dual-purpose \\
\hline Cows (head) & $300-400$ & $180-200$ & $2-10$ \\
Lactation days & 305 & $280-305$ & $210-260$ \\
Milk yield (1 per cow per d) & $20-27$ & $18-20$ & $6-12$ \\
\hline
\end{tabular}


$18 \%$ protein seems to a doubling the protein amount present in grasses (Faría 2006). Within this context, the incorporation of legumes in the system of pastures is especially important because the high content of protein and its capability to improve soil fertility through the symbiotic fixation of the atmosphere nitrogen. Despite, there is broad knowledge in the legumes agronomic aspects, their use has not been wide-spread yet, as most of them show low persistence in grassing conditions or in association with grasses. One of the few exceptions seems to be pinto peanut (Arachis pintoi), a legume which has provided satisfactory results in grazing (Fernández-Baca 1992; Ruiz et al. 2005).

The use of trees and bushes as forage sources is not fully understood, and despite the fact that there are several identified species, their usefulness in the feeding cattle is unknown and neither there is information on the nutritional quality and the plants' utilization methodology (Faría 2006).

The presence or introduction of trees and other plants as forage sources, the situation of introduces are new interactions and different dynamics, appearing as a vitally important component which is that of the agroforestry systems of livestock production (Murgueitio 1999), which is nothing but a livestock system whose components are trees, crops and animals, present on the same land.

The agrosilvopastoral systems are another option that farmers used, as their necessary to achieve new alternatives, biologically, economically and ecologically more sustainable than those traditional in the use of land, mainly compared to the grass grazing and single crop systems (Murgueitio 1999). Such systems have also a great potential for improving degraded grassing lands. In tropical regions, the integration of cattle and trees will tend to reproduce, partly, the ecological benefits provided by the original flora and contribute to reduce the negative ecological impacts of deforestation to create grasslands (Faría 2006).

Another option is the establishment of pastures with improved grasses and an appropriate implementation of technically improved grazing. Likewise, given the restrictions of forage availability along the year, the farmer can adopt technologies that guarantee forage availability for dry the season, such as forage preservation (hay, silage), the use of irrigation systems or turn to the use of energy and or protein (non-protein nitrogen and true protein) supplementation as alternatives sources (Castillo et al. 1999).
Feed supplementation

To decrease the negative effects of low forage availability during dry season, farmers must use protein and energy supplementation in a strategic manner. The high fiber and low nitrogen contents; and low digestibility of the grasses would suggest supplementation with protein, either as non-protein nitrogen or rumen bypass proteins (Nicholson et al. 1994; Aguilar-Pérez 1997; Castillo et al. 1999).

Despite that forages supply most of the mineral elements required by the animal, many of the forages have deficient and marginal levels for some elements; it is widely demonstrated that supplying macro and micro minerals in pre-mixes, offered ad libitum, is one of the most efficient ways to improve reproductive response from 5 to $50 \%$ in cattle (Corah 1996; Franco 2006).

\section{Use of reproductive techniques}

One of the main problems detected in DPS is the low reproductive efficiency, characterized by extended postpartum anoestrus. This situation results in economic losses for the farmers because of the long parturition intervals. In order to solve it, there are several technologies available.

Restrictive suckling to control the cow-calf interaction

It has been demonstrated that suckling and nutrition are the main factors that determine postpartum anoestrus duration in dual purpose cows (PérezHernández 1992; Das et al. 1999; Villa-Godoy and Villagómez 2000). Therefore, the regulation of the suckling stimulus, together with better feeding schemes are the best options for its reduce (Das et al. 1999; Galina et al. 2001; Pérez-Hernández et al. 2002a).

Several options that have been studied, at nonetheless, in dual purpose cows the calf's full weaning at days or weeks of age (precocious or temporary weaning), suckling restriction to short periods during the day (restricted suckling or controlled lactation) and delayed suckling are alternatives and easily to implement by farmer (Galina et al. 2001; PérezHernández et al. 2002b; Hernández et al. 2006). 
Body condition and nutrition

Low availability and quality of grass, associated with a little or no use of feed supplements in the tropics, cause the un-fulfillment of the nutritional requirements of livestock (Villa-Godoy and Villagómez 2000) as well as low body conditions in the different physiologic states of the animal. Due to the aforementioned, the farmers are required to evaluate cow's body condition score before, at and after birth, so, based on such evaluation, elaborate programs to strategically supplemental feeding, mainly during forage low availability. It has been demonstrated that in Bos taurus x Bos indicus cows managed in dual purpose systems, with or without suckling, energetic supplementation during the postpartum period decreases in the interval birth-first ovulation-first estrous and to conception (Villa-Godoy and Villagómez 2000).

Male effect

Another option available for farmers is to expose the cows to the bull few days after parturition, it has been demonstrated that this manage practice cows are able to have their first ovulation within 50 days after birth. This is a simple technique for the farmers to establish it in order to decrease the postpartum anoestrus (Burns and Spitzer 1992; Pérez-Hernández et al. 2002a; Espinoza et al. 2007).

\section{Sustainable dual purpose cattle}

The challenge faced by dual purpose cattle in Mexico and Latin America is to achieve accelerated and sustained development, along with high terminal efficiency, which would then allow to meet the milk and meat demands of a fastly growing population, to guarantee the conservation of the natural resources (Rivas and Holmann 2002).

The use of foraging trees, shrubs and grasses can improve the soils' physical and chemical conditions, and decrease fertilization. Moreover, the coexistence of herbaceous, woody and grass plants allows the animals to have a variable source of food and the plants to have an equilibrated growth pace as well as decreasing the deterioration of pastures (Ruiz et al. 2005).
The agrosilvopastoral system with integrating trees, with cattle, alternatively or simultaneously increases the pasture's productivity. There are various options to farmers for adopt, such as the following: 1) specialized and intensive forage production systems, for cut forage, 2) Use of trees as live barriers (live fences, windbreaker curtains, etc); 3) Protein bank with foraging trees and legumes; and 4) Trees or shrubs scattered in grasslands, where animals grass directly with the trees. According to this technology, animals and hectare weight gain was improved, which is very important during the dry season. The calves under restricted suckling are able to improve their weight gain and reduce feeding costs for commercial food. This becomes important as most of the small farmers can not afford to purchase commercial concentrates to strategically feed dual purpose cows (Ruiz et al. 2005; Magaña et al. 2006).

\section{Conclusions}

Dual purpose cattle have an enormous importance in tropical climates because of its low-investment requirements and its great flexibility. However, the high productivity levels are non existent; by means of improving its productivity and profitability.

Technologies such as controlled, restricted or delayed suckling and the strategic nutritional supplementation are viable option to farmer for implementation and decreasing the negative effects produced by the calf's presence and suckling in cows. To implement some of the strategies of suckling management and improve the productive and reproductive efficiency of dual purpose cattle exploitations must be taken into account and not to be affect calf's development, maintain lactation and milk production.

To optimize the use of grasses, the producers are required to adapt breeding seasons, to a restricted period of the year, seeking cows to become pregnant in early summer, either through artificial insemination or mounting.

The use of multipurpose trees in the agrosilvopastoral system is an option the dual purpose farmers to improve the soil nutrient recycling, preserve biodiversity and soil's organic matter, as well as reducing the negative environmental impact of dual purpose cattle exploitations with traditional management. 


\section{References}

Aguilar-Pérez, C.F., 1997. Suplementación y productividad de vacas lactantes de doble propósito en praderas tropicales, Agrociencia, 31, 391-396.

Burns, P.D., Spitzer, J.C., 1992. Influence of biostimulation on reproduction in postpartum beef cows, Journal of Animal Science, 70, 358.

Castillo, G.P., Ocaba, Z., Mendoza, P., Gómez, S., Rubio, G., Livas, C., y Aluja, S., 1999. Complementos con base en melaza-urea para vacas de doble propósito del trópico veracruzano. Veterinaria México, 30, 125-133.

Corah, L., 1996. Trace mineral requirements of grazing cattle. Animal Feed Science and Technology, 59, 61-70.

Das, S.M., Forsberg, M., and Wiktorsson, H., 1999. Influence of restricted suckling and level of feed supplementation on postpartum reproductive performance of zebu and crossbred cattle in the semi-arid tropics, Acta Veterinaria Scandinavica, 40, 57-67.

Del Valle, R.M.C., y Álvarez, M., 1997. La producción de leche en México en la encrucijada de la crisis y los acuerdos del TLCAN. In: Proceedings of XX International Congress of the Latin American Studies Association, Guadalajara, México April 1997, 18.

Espinoza-García, J.A., Matus-Gardea, J.A., Martínez-Damián, M. A., Santiago-Cruz, M.J., Román-Ponce, H. and BucioAlanís, L., 2000. Análisis económico de la tecnología bovina de doble propósito en Tabasco y Veracruz, Agrociencia, 34, 651-661.

Espinoza, V.J.L., López, R.A.,Palacios, A.E., Ortega, R.P., Ávila, N.S., y Murillo, B.A., 2007. Efecto del toro sobre el comportamiento estral de vacas Chinampas (Bos taurus) en una región tropical seca, Zootecnia Tropical, 25, 19-28.

Faría, M.J., 2006. Manejo de pastos y forrajes en la ganadería de doble propósito. In: Memorias de X Seminario Manejo y Utilización de Pastos y Forrajes en Sistemas de Producción Animal, LUZ-FCV, Maracaibo, Venezuela, April 2006, 9.

Fernández-Baca, S., 1992. Perspectivas de la producción de leche y carne en el trópico americano. In: S. Fernández Baca (ed.) Avances en la Producción de Leche y Carne en el Trópico Americano. FAO, Oficina Regional para América Latina y el Caribe. Santiago, Chile, 483-504.

FIRA, 2001. Tendencias y oportunidades de desarrollo de la red lechera en México. Boletín Informativo, No. 317.

Franco, M., 2006. Strategies to enhance fertility in dairy cattle during summer including use of cryopreservation of in vitro produced embryos, (unpublisehd. MSc Thesis, University of Florida),

Galina, C.S., Rubio, I., Basurto, H., and Orihuela, A., 2001. Consequences of different suckling systems for reproductive activity and productivity of cattle in tropical conditions, Applied Animal Behaviour Science, 72, 255-262.

Gallegos-Sánchez, J., 1990. Efecto del retraso del amamantamiento en el restablecimiento de la función reproductiva en vacas Bos taurus x Bos indicus durante el período posparto, (no publicada, Tesis de Maestría,Colegio de Postgraduados, México).

Gómez, C.H., Tewolde, A.M. and Nahed, J.T., 2002. Análisis de los sistemas ganaderos de doble propósito en el centro de Chiapas, México, Archivos Latinoamericanos de Producción Animal, 10, 175-183.

González-Padilla, E., 1993. Situación actual y perspectivas de la producción de leche en la ganadería de doble propósito en las regiones tropicales. In: Memorias del XVI Simposio de ganadería Tropical, Instituto de Investigación Forestal y Agropecuario, Secretaría de Agricultura y Recursos Hidraúlicos, Veracruz,México, 1-14.

Hernández, C., Orihuela, A., Fröberg, S., and Lidfors, L. M.,2006. Effect of restricted suckling on physiological and behavioural stress parameters in dual-purpose cattle in the tropics, Livestock Science, 99, 21-27.

INEGI. 2008. Anuario estadístico de los Estados Unidos Mexicanos, Edición 2007. Instituto Nacional de Estadística, Geografia e Informática,ISSN 0188-8692, 158.

Juárez, L.F.I., Fox, D.G., Blake, R.W., and Pell, A.N., 1999. Evaluation of tropical grasses for milk production by dualpurpose cows in tropical México,. Journal of Dairy Science, 82, 2136-2145.

Magaña, M.J.G., Ríos, G.A., y Martínez, J.C.G., 2006. Los sistemas de doble propósito y los desafíos en los climas tropicales de México, Archivos Latinoamericanos de Producción Animal, 14, 105-114.

McDowell, R.E., 1996. Sistemas ganaderos de doble propósito: situación actual y prioridades para el futuro. In: Curso de actualización: Aspectos nutricionales del ganado de doble propósito en el trópico,Tlapacoyan, Veracruz, 1-14.

Murgueitio, E., 1999. Reconversión ambiental y social de la ganadería bovina en Colombia. Foundation of Agriculture Organization, Roma, World Animal Review, 93,2, 2-15.

Nicholson, C.F., Blake, R.W., Urbina, C.I., Lee, D.R., Fox, D. G., and Van Soest, P.J., 1994. Economic comparison of nutritional management strategies for venezuelan dualpurpose cattle systems, Journal of Animal Science, 72, 1680-1696.

Pérez-Hernández, P., 1992. Efecto del amamantamiento y presencia del macho en el restablecimiento de la actividad reproductiva postparto en vacas Bos taurus x Bos indicus en un sitema de rejeguería, (no publicada, Tesis de Maestría,. Colegio de Postgraduados, México).

Pérez-Hernández, P., García-Winder, M., and GallegosSánchez, J., 2002a. Bull exposure and an increased within-day milking to suckling interval reduced postpartum anoestrus in dual purpose cows, Animal Reproduction Science, 74, 111-119.

Pérez-Hernández, P., García-Winder, M., and Gallegos-Sánchez, J., 2002b. Pospartum anoestrus is reduced by increasing the within-day milking to suckling interval in dual purpose cows, Animal Reproduction Science, 73, 159-168.

Rivas, L., and Holmann, F., 2002. Sistemas de doble propósito y su viabilidad en el contexto de los pequeños y medianos productores en América Latina Tropical. In: Curso Internacional de Actualización en el Manejo de Ganado Bovino de Doble Propósito, Veracruz, México, November 2002, 1-38.

Rivera, M.D., Núñez, R., y Fernández, S., 1989. Comportamiento reproductivo y productivo de vacas Holstein-Cebú y Suizo Pardo-Cebú en un hato de doble propósito, Revista Chapingo, 65-66, 31-33.

Rodríguez-Chessani, M.A., y Sordo, M., 1995. Comportamiento productivo de becerros de doble propósito (nacimiento- 
destete) bajo condiciones tropicales. In: Memorias de Reunión Nacional de Investigación Pecuaria en México, Veterinaria México, 36, 399.

Ruiz, T.E., Febles, G., Jordán, H., y Castillo, E., 2005. Legumes: their possibilities to implant sustainable cattle systems. Cuban Journal of Agricultural Science, 39, Special Issue, 485-498.

SAGARPA., 2005. Situación actual y perspectiva de la producción de leche de bovino en México 2005 Coordinación General de Ganadería, Secretaría de Agricultura, Ganadería, Desarrollo Rural, Pesca y Alimentación.
SAGARPA. 2006. Situación actual y perspectiva de la producción de carne de bovino en México 2006. Coordinación General de Ganadería, Secretaría de Agricultura, Ganadería, Desarrollo Rural, Pesca y Alimentación.

Villa-Godoy, A., y Villagómez, A.E., 2000. Influencia de la dieta y el amamantamiento en el balance energético, la condición corporal, la producción láctea, el metabolismo y el desempeño reproductivo en vacas de doble propósito. In: Curso Internacional de Reproducción Bovina, Universidad Nacional Autónoma de México, México, 167-215. 